\title{
Decreasing Vulnerabilities Being Revealed During Stressors and Increasing Resilient Characteristics: The Role of Goal Commitment in Team Sports
}

\author{
Ender Şenel ${ }^{1}$ (D), Mehmet Ulaş² \\ 'Mugla Sitki Kocman University, Faculty of Sport Sciences \\ ${ }^{2}$ Burdur Mehmet Akif Ersoy University, Faculty of Sport Sciences
}

Research Article

DOI:10.53434/gbesbd. 1006847

\begin{abstract}
Recent studies in sport psychology have focused on resilience and performance in sport. As an important psychological performance determinant in elite performance, resilience studies included team and individual athletes. This study provides a different perspective to resilience studies with goal commitment approach. Goal commitment is one of the recent factors being examining in sports. The aim of this study to examine the role of goal commitment in team and individual resilience in sport. Two hundered eightynine team athletes $\left(M_{\text {age }}=20.18 \pm 4.69\right)$ completed commitment and resilience measures. Different mediation models indicating the role of goal commitment was hypothesized. The mediation model analysis revealed that goal commitment was a critical component of resilience in sport since it had a necessary role to increase resilience and decrease vulnerabilities when encountered setbacks.
\end{abstract}

Keywords: Resilience, Commitment, Team sports, Athletic performance 


\title{
Stres Tetikleyiciler Esnasında Gösterilen Zayıflıkları Azaltma ve Direnç Özelliklerini Artırma: Takım Sporlarında Hedef Bağlılığının Rolü
}

\author{
Araştırma Makalesi
}

Öz

Spor psikolojisindeki son çalışmalar, sporda direnç ve performansa odaklanmıștır. Elit performansta önemli bir psikolojik performans belirleyicisi olarak, direnç çalışmaları takım ve bireysel sporcuları içermektedir. Bu çalışma, hedef bağlılığı yaklaşımı ile direnç çalışmalarına farklı bir bakış açıSı sunmaktadır. Hedef bağlılığı, sporda son zamanlarda incelenen faktörlerden biridir. Bu çalışmanın amacı, sporda takım ve bireysel dayanıklılıkta hedefe bağllığın rolünü incelemektir. Araștırmaya, takım sporcuları dahil edilmiştir ve bağlllık ve direnç ölçeklerini yanıtlamıștır. Hedef bağlılığının rolünü gösteren farklı aracılık modelleri varsayılmıştır. Aracılık modeli analizi, hedeflere bağlılı̆ın sporda direncin kritik bir bileşeni olduğunu ortaya koymuştur, çünkü aksiliklerle karş̧laşıldığında direnci artırmak ve zayıflıkları azaltmak için gerekli bir role sahiptir.

Anahtar sözcükler: Direnç, Bağlılık, Takım sporları, Sportif performans

\section{Introduction}

Limited studies into goal commitment perspective in sports field focused on goal and performance relationships (Barnett, 1977; Barnett \& Stanicek, 1979; Hollingsworth, 1975; Theodorakis, 1996). The concept of goal commitment has an important place in performance. The degree of commitment of individuals to their goals plays an important role in determining how easily a person is able to give up when faced with difficulties, how likely they are to be lazy in the absence of external pressure, the likelihood of abandoning difficult goals, and how likely they are to "leave the field" when faced with stress (Locke, 1968). Goal commitment refers to the determination to strive for a goal. Commitment refers to the prolongation of the effort spent over time towards achieving an original goal and emphasizes the reluctance to abandon the original goal or to lower the target (Campion \& Lord, 1982). In the goal commitment perspective, being committed to a goal belonging to a group or an individual means to withstand the difficulties to reach what is set for a goal. Resilience in sport has similar meaning focuses with goal commitment. Without commitment, displaying resilient characteristics does not seem possible.

Studies into resilience in sports team have drawn attention to find out the coping strategies to prevent effects of harmful stressors with the term team resilience (Morgan, Fletcher \& Sarkar, 2013; 2019). When facing adversity, athletes can react in different ways or display different pattern of behaviors. They may have different strategies to deal with the adversity when they encounter in the field. Athletes can rely on their abilities while some can use the support they perceive from significant others. Studies have showed that athletes competing in team sport enhance performance by perceiving social support and beliefs in their team. Athletes can identify the opportunities to be used against stressors 
(Galli \& Gonzalez, 2015; Meneghel, Salanova \& Martinez, 2016; Sarkar, 2017). Because the protective nature from potentially harmful effects of stressors (Morgan, Fletcher \& Sarkar, 2017), team resilience is considered as one of the psychological performance predictors in team sports. Individual resilience in sport also helps athletes to withstand the pressures (Sarkar \& Page, 2020). Individual level of resilience characteristics can have impact on decreasing the harmful effects of stressors. Athletes make efforts to deal with the stressors they encounter in their teams individually. Therefore, individual resilience abilities become important as well as team abilities. However, there is limited studies examining the structure of measuring individual resilience in sports field. So, team resilience measurement was adapted to individual-level measurement by analyzing the structure in team athletes. Fletcher and Sarkar (2016) explained the importance of having resilient individuals in a team, however this is not an indicator that the team will have the ability to stay resilient under pressure. In the same study, it is well stated that the team should have group goal commitment to have this ability.

Commitment is an important factor to build individual and team resilience (Sarkar \& Page, 2020). Because teams and their members try to reach the same goals they work together, and they withstand the obstacles collectively, being committed to these goals can play an important role to enhance the resilient characteristics. Goal commitment refers to the determination to strive for a goal (or to continue to strive for a goal) (Locke, Shaw, Saari, \& Latham 1981). Goal commitment has a critical role in determining performance (Hollenbeck \& Klein, 1987). Goal commitment is high when the individual is highly motivated and determined to achieve the goal. Goal commitment increases actual and anticipated performance (Riedel, Nebeker \& Cooper, 1988).

Group goals in sports field may become individual goals in time when a team is focused on reaching collective goals. Individual and team goals become prominent to foster a motivation to be resilient via commitment. Correspondingly, two important questions arise: a) what the role of athletes' commitment to team and individual goals is to decrease the vulnerabilities when encountered stressors, and b) what the role of athletes' commitment to team and individual goals is to increase resilient characteristics. Although the relationships between resilience and commitment have been examined in some area including education (Day \& Gu, 2009; Martin \& Marsh, 2003), management (Mangundjaya \& Amir, 2021), there is no study examining the direct and indirect roles of commitment to decrease vulnerabilities when faced with stressors and increase the individual and team abilities to display resilient characteristics in sports field.

This study provides two important findings; one is an adapted version of team resilience inventory to assess individual resilience in sports field, second is the role of goal commitment to increase individual and team resilient characteristic and decrease vulnerabilities when faced with stressors. This study presented in this paper aims to examine the role of goal commitment at individual and team level in team functioning when face with stressors. 
Model Hypotheses are as follows:

Mediation model 1: Displaying resilient characteristics (Individual) predicts vulnerabilities being revealed during stressors (team) via commitment to team goals $\left(\mathrm{H}_{1}\right)$.

Mediation model 2: Displaying resilient characteristics (team) predicts vulnerabilities being revealed during stressors (individual) via commitment to team goals $\left(\mathrm{H}_{2}\right)$.

Mediation model 3: Displaying resilient characteristics (team) predicts vulnerabilities being revealed during stressors (individual) via commitment to individual goals $\left(\mathrm{H}_{3}\right)$.

Mediation model 4: Displaying resilient characteristics (team) predicts vulnerabilities being revealed during stressors (team and individual) via commitment to team goals $\left(\mathrm{H}_{4}\right)$.

Mediation model 5: Displaying resilient characteristics (team) predicts vulnerabilities being revealed during stressors (team and individual) via commitment to individual goals $\left(\mathrm{H}_{5}\right)$.

Mediation model 6: Commitment to team goals predicts vulnerabilities being revealed during stressors (team and individual) via displaying resilient characteristics (team) $\left(\mathrm{H}_{6}\right)$.

Mediation model 7: Commitment to team goals predicts displaying resilient characteristics (Individual) via commitment to individual goals $\left(\mathrm{H}_{7}\right)$.

Mediation model 8: Commitment to individual goals predicts displaying resilient characteristics (Individual) via commitment to team goals $\left(\mathrm{H}_{8}\right)$.

Mediation model 9: Resilient characteristics (team) predicts resilient characteristics (individual) via commitment to team goals $\left(\mathrm{H}_{9}\right)$.

Mediation model 10: Resilient characteristics (team) predicts resilient characteristics (individual) via commitment to individual goals $\left(\mathrm{H}_{10}\right)$.

Mediation model 11: Resilient characteristics (team) predicts resilient characteristics (individual) via commitment to team and individual goals $\left(\mathrm{H}_{11}\right)$.

\section{Method}

\section{Participants}

Inclusion Criteria

Athletes were recruited based on following criteria:

a) They should have three years of experience in sports.

b) They should be competing for a team sport for at least a year.

c) They should be over 18-year-old.

d) They should be working with the same coach for at least a year.

A generally accepted minimum level of power is 0.80. A commonly used interpretation is to refer to effect sizes as small $(d=0.2)$, medium $(d=0.5)$, and large $(d=$ 0.8 ) based on benchmarks suggested by (Cohen, 1988). The G*Power (Ver. 3.1, University of Duesseldorf, Germany) package program was used to determine the sample size of the study. G*Power analysis was performed using Linear Multiple Regression: Fixed Model, R2 deviation from zero test. No study has been found in the literature that has similar characteristics with the research. For this reason, it was assumed that the mediator 
variables discussed could have a moderate effect on goal commitment in team sports, and the $\mathrm{f} 2$ value was defined as 0.095 according to the reference values created by Cohen (Cohen, 1988, pp. 413-414). Since the research was conducted with a 95\% confidence interval, the alpha error was accepted as $\alpha=0.05$, and the power of the research was determined as $\beta=0.95$ to avoid beta error. Power analysis was carried out with 11 predictors of the research and their determined values, and as a result of the analysis, it was determined that the minimum sample number of the research was 275 . In this context, 289 team athletes were included in the study based on inclusion criteria. Athletes were asked to state if they were professional (refers to both the category of the league and athletes doing the sport as a profession) and, semi-professional (refers to competing in an amateur league category but earning some money), and amateur (refers that league is in an amateur category and the athletes earning no money). International level describes that the athletes competed for the national team at least in one international match (friendly or tournament).

Table 1. Overall descriptive statistics for participants

\begin{tabular}{|c|c|c|c|c|}
\hline Variables & & $\mathbf{n}$ & $\%$ & $\bar{X} \pm \sigma$ \\
\hline \multirow{2}{*}{ Gender } & Female & 103 & 35.6 & \\
\hline & Male & 186 & 64.4 & \\
\hline \multirow{3}{*}{ Category } & Amateur & 181 & 62.6 & \\
\hline & Semi-Professional & 42 & 14.5 & \\
\hline & Professional & 66 & 22.8 & \\
\hline \multirow{6}{*}{ Branch } & Football & 84 & 29.1 & \\
\hline & Basketball & 63 & 21.8 & \\
\hline & Volleyball & 42 & 14.5 & \\
\hline & Handball & 43 & 14.9 & \\
\hline & Hockey & 34 & 11.8 & \\
\hline & American Football & 23 & 8.0 & \\
\hline \multirow{2}{*}{ International Level } & Yes & 54 & 18.7 & \\
\hline & No & 235 & 81.3 & \\
\hline Age & & & & $20.18 \pm 4.69$ \\
\hline Experience & & & & $8.11 \pm 6.14$ \\
\hline Training day per week & & & & $3.82 \pm 1.40$ \\
\hline Training Duration per day & & & & $2.16 \pm 0.73$ \\
\hline Playing for Current Team & & & & $2.71 \pm 2.45$ \\
\hline
\end{tabular}

\section{Design and Procedure}

Institutional ethical approval was granted prior to the study (2020/4, G02020/102). We designed the structure of the form included the measurements. Before the study, we designed the measurements, asked field experts to share their opinions about the measurements in Turkish and used these opinions to analyze the construct of the measurement. After finishing the construct validity analyses, we sent the form to the coaches for sharing it to the athletes. After collecting 415 data, we excluded 126 data that did not meet the inclusion criteria, then, started to analyze the data.

\section{Measures}

Team Resilience: The Characteristics of Resilience in Sports Teams Inventory (CREST) consists of 20 items with two sub-dimensions including "team ability to demonstrate resilience characteristics" and "vulnerabilities being revealed under stressors" Decroos et 
al. (2017) developed the original inventory and Gorgulu, Senel, Adilogullari, and Yildiz (2018) translated it into Turkish. The measurement is a self-report questionnaire that is designed to measure resilience characteristics and vulnerabilities shown under pressure of athletes competing in team sports. The athletes rated each item 1 (strongly disagree) and 7 (strongly agree). In the demonstrating resilience characteristics dimension, each item presents a resilient characteristic shown under pressure in the past month while each item in vulnerabilities shown under pressure displays a weakness of the team that the athletes perceive. The internal consistency of team ability to demonstrate resilient characteristics was 0,92 and the one of vulnerabilities being revealed during stressors was 0,91 . "The team was able to focus on what was important" is an example for team ability to demonstrate resilience characteristics and "teammates started to communicate negatively with each other" is an example for vulnerabilities being revealed under stressors.

Individual Resilience: The CREST items were revised to assess athletes' resilient perception about themselves. The revised version of the items was sent to field expert to be rated between 1-4 if the items were proper to assess individual perception of resilient characteristics in sport. "I was able to focus on what was important" is an example for individual ability to demonstrate resilience characteristics and "I started to communicate negatively with my teammates" is an example for vulnerabilities being revealed under stressors. The content and construct validity for the revised version of CREST was conducted by following expert opinions and confirmatory factor analysis process.

Commitment to Team and Individual Goals: Unidimensional Target-Free (KUT) commitment scale was used to assess athletes' commitment to individual and team goals by designing the items to measure commitment to individual and team goals in sports environment. KUT is a scale consisting of four items, one-dimensional and used with 5 or 7 ratings. The scale consists of four items developed by Klein, Molloy and Brinsfield (2012) according to commitment definition. While the first item expresses the general structural characteristic, the second refers to the dedication to the goal. The third one refers to the will or volition for commitment and the last item is related to the responsibility associated with the goal. Klein, Cooper, Molloy andSwanson (2014) tested the structure of the scale in five different sample groups, collecting data from 2487 participants from various environments, professions, organizations, and industries. The Cronbach's alpha coefficient of the scale ranged from 0.86 to 0.97 . Senel, Yildiz and Klein (2020) translated the scale into Turkish and tested the validity and reliability. The alpha coefficient of Turkish version was 0,92 . "How committed are you to your team's goals?" is an example for commitment assessment to team goals, and "How committed are you to your individual goals?" is an example for individual goals.

Analyses

Preliminary Analyses: We examined the data to determine the pattern of missing scores and assessed the normality of data by examining the skewness and kurtosis scores. We also examined the construct validity of revised version of resilience measurement by conducting CFA and the content validity by calculating the content validity index, and also 
investigated the Cronbach's alpha coefficients of all scales, run CFA for commitment measurement which had limited validity evidence in sport context. With universal agreement calculation method, item-level and scale-level content validity indexes were calculated by using expert ratings (Lynn, 1986; Waltz \& Bausell, 1981). Pearson correlation coefficients between study variables were also reported. CFA procedures to test fit of the measurements to the data by choosing maximum likelihood method. We utilized cutoff criteria suggested by $\mathrm{Hu}$ and Bentler (1999) to evaluate model fit indexes for CFA $\left(x^{2} / \mathrm{df} \leq\right.$ 3 , CFI and TLI $\geq .95$, RMSEA $\leq .06$, SRMR $\leq .08$ ). Since we tested some hypotheses in this paper, we consider two issues to avoid Type I and Type II errors. It is recommended that Type I and Type II error can be avoided by increasing sample size and significance level. We consider the selecting proper study group to test the hypotheses. The inclusion criteria can somehow provide a proper study group. To avoid Type II error, increasing significance level inappropriately may increase the probability of Type I error. In this manner, we decided to accept 0.05 as the significance level to test the hypotheses.

Testing Mediation Models: We tested mediation models between resilience characteristics, commitment to the goals and displayed vulnerabilities, and proposed one and two mediator models, two outcome models to decrease vulnerabilities revealed during stressors and to increase resilient characteristics with the role of goal commitment. We applied a two-index presentation method proposed by Hu and Bentler (1999) to assess the fit of the data to the models, by reporting Standardized Root Mean Square Residual (SRMR) with Comparative Fit Index (CFI) and Incremental Fit Index (IFI). Values of close to .95 or above shows perfect fit of the model to the data for CFI and IFI while values close to 0.08 indicate a well-specified model (Hu \& Bentler, 1999). We included confidence Intervals for parameter estimates at $95 \%$. We used bias-corrected percentile method with two-tailed significance.

\section{Results}

There were no missing data. We tested the normality with Skewness and Kurtosis scores for individual variables. Some of the Kurtosis scores for individual variables were higher than 3, indicating non-normality (Westfall \& Henning, 2013) while some under 1. As Mardia's coefficient was 43,85 with the critical ratio of 38,04, data depart from multivariate normality. Therefore, we operate bootstrapping method procedure with 5000 bootstrap replication samples to calculate more accurate parameter estimates (Byrne, 2001).

In this study, the Cronbach's alpha coefficient of team ability to demonstrate resilient characteristics was 0,93 and of team vulnerabilities being revealed during stressors was 0,91 . The data fit to the model in CFA of team resilient measurement $\left[\chi^{2}(\mathrm{df}=169)=\right.$ $413,900(\mathrm{p}<.01)$, RMSEA $=.07(90 \% \mathrm{CI}=.06-.08)$, TLI $=.92, \mathrm{CFI}=.93$, IFI=0,93 SRMR = .04.]. Table 2 shows the expert ratings for revised version of CREST. The Cronbach's alpha of individual ability to demonstrate resilient characteristics was 0,88 and of individual vulnerabilities being revealed during stressors was 0,88 . The data fit to the model in CFA of individual resilient measurement $\left[\chi^{2}(\mathrm{df}=169)=406,561(\mathrm{p}<.01)\right.$, RMSEA $=.07(90 \%$ 
$\mathrm{CI}=.06-.07)$, TLI $=.91, \mathrm{CFI}=.92$, IFI $=.92$, SRMR $=.05]$. CFA of the resilient measurements data supported the factorial validity of 20 -item inventories.

Table 2. Content validity of revised version of CREST

\begin{tabular}{|c|c|c|c|c|c|c|c|c|}
\hline Item & Rater 1 & Rater 2 & Rater 3 & Rater 4 & Rater 5 & Rater 6 & $\begin{array}{c}\text { Number of } \\
\text { agreements }\end{array}$ & I-CVI \\
\hline 1 & 4 & 4 & 4 & 3 & 4 & 3 & 6 & 1 \\
\hline 2 & 4 & 3 & 4 & 3 & 3 & 3 & 6 & 1 \\
\hline 3 & 2 & 4 & 3 & 4 & 4 & 4 & 5 & 0,83 \\
\hline 4 & 4 & 3 & 3 & 4 & 4 & 4 & 6 & 1 \\
\hline 5 & 3 & 4 & 4 & 4 & 4 & 4 & 6 & 1 \\
\hline 6 & 3 & 3 & 3 & 3 & 3 & 3 & 6 & 1 \\
\hline 7 & 3 & 3 & 4 & 3 & 4 & 2 & 5 & 0,83 \\
\hline 8 & 4 & 4 & 3 & 3 & 4 & 2 & 5 & 0,83 \\
\hline 9 & 4 & 3 & 3 & 2 & 4 & 3 & 5 & 0,83 \\
\hline 10 & 4 & 4 & 4 & 4 & 4 & 4 & 6 & 1 \\
\hline 11 & 3 & 3 & 4 & 2 & 4 & 3 & 5 & 0,83 \\
\hline 12 & 4 & 3 & 4 & 4 & 4 & 4 & 6 & 1 \\
\hline 13 & 3 & 4 & 4 & 4 & 4 & 4 & 6 & 1 \\
\hline 14 & 4 & 3 & 4 & 4 & 3 & 4 & 6 & 1 \\
\hline 15 & 3 & 4 & 3 & 4 & 4 & 4 & 6 & 1 \\
\hline 16 & 4 & 4 & 4 & 4 & 4 & 3 & 6 & 1 \\
\hline 17 & 4 & 3 & 4 & 3 & 4 & 2 & 5 & 0,83 \\
\hline 18 & 3 & 4 & 4 & 3 & 4 & 2 & 5 & 0,83 \\
\hline 19 & 4 & 4 & 3 & 4 & 4 & 3 & 6 & 1 \\
\hline \multirow[t]{2}{*}{20} & 3 & 4 & 3 & 4 & 4 & 3 & 6 & 1 \\
\hline & & & & & & & $\begin{array}{c}\text { S-CVI } \\
\text { Total Agreement } \\
\text { S-CVI/UA }\end{array}$ & $\begin{array}{c}0,94 \\
13 \\
0,65\end{array}$ \\
\hline
\end{tabular}

Item level content validity index (I-CVI) ranged between 0,83 and 1,0 while scale level content validity index was 0,94 . According to universal agreement calculation method, $\mathrm{S}$ CVI/UA was 0,65.

For commitment measures, in this study, the alpha internal consistency coefficient of the scale is 0.90 . The scale has a one-dimensional structure consisting of 4 items. The Cronbach's alpha coefficient of commitment measurement to team goals was 0,95 while the coefficient of measurement for individual goals was 0,94 . The data was fit to the models for both commitment to team $\left[\chi^{2}(\mathrm{df}=1)=0,444(\mathrm{p}<.01)\right.$, RMSEA $=.00(90 \% \mathrm{CI}=.00-.13)$, TLI $=1.0, \mathrm{CFI}=1.0, \mathrm{IFI}=1.00, \mathrm{SRMR}=.00)$ and individual goals $\left(\chi^{2}(\mathrm{df}=1)=2,296(\mathrm{p}<.01)\right.$, RMSEA $=.06(90 \% \mathrm{CI}=.00-.18), \mathrm{TLI}=0.99, \mathrm{CFI}=0.99, \mathrm{IFI}=0.99, \mathrm{SRMR}=.00]$.

\section{Testing the mediation models}

Table 3. Mean, standard deviation and correlations between study variables

\begin{tabular}{|c|c|c|c|c|c|c|}
\hline & $\overline{\boldsymbol{X}} \pm \sigma$ & 1 & 2 & 3 & 4 & 5 \\
\hline 1. Team resilient characteristics & $5.63 \pm 1.20$ & 1 & & & & \\
\hline 2. Individual resilient characteristics & $5.83 \pm 1.00$ & $.649^{* *}$ & 1 & & & \\
\hline $\begin{array}{l}\text { 3. Team vulnerabilities being revealed } \\
\text { during stressors }\end{array}$ & $2.54 \pm 1.46$ & $-.723^{* *}$ & $-.552^{* *}$ & 1 & & \\
\hline $\begin{array}{l}\text { 4. Individual vulnerabilities being revealed } \\
\text { during stressors }\end{array}$ & $2.57 \pm 1.46$ & $-.483^{* *}$ & $-.471^{* *}$ & $.664^{* *}$ & 1 & \\
\hline 5. Commitment to team goals & $6.46 \pm 1.00$ & $.493^{* *}$ & $.670^{* *}$ & $-.539^{* *}$ & $-.371^{* *}$ & 1 \\
\hline 6. Commitment to individual goals & $6.34 \pm 1.09$ & $.386^{* *}$ & $.621^{* *}$ & $-.388^{* *}$ & $-.295^{* *}$ & $.715^{* *}$ \\
\hline
\end{tabular}


In table 3, the correlations show that the study variables meet the criteria to be included in mediation analysis since the variables are associated with each other significantly. These results also indicate that individual-level and team-level are not the same measurement because the correlations between them are lower than 0,90 .

Decreasing Mediation Models (One Mediator Analyses)

Mediation model 1: Displaying resilient characteristics (Individual) predicts vulnerabilities being revealed during stressors (team) via commitment to team goals

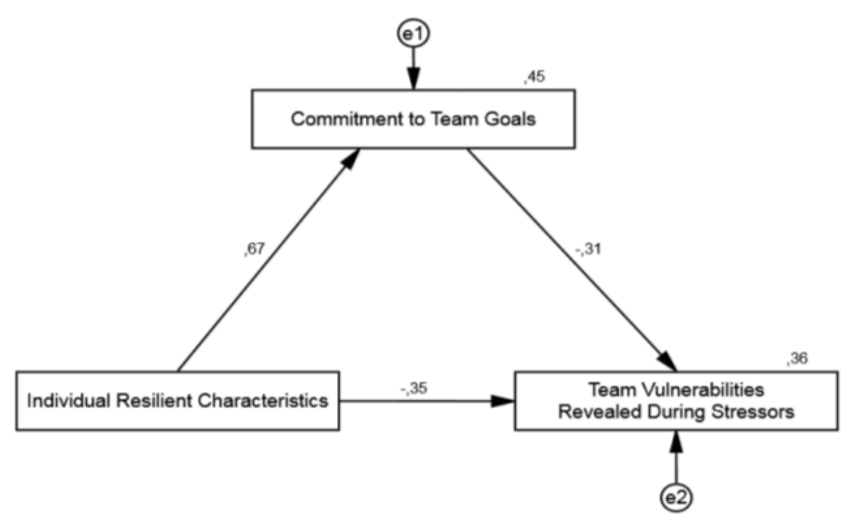

Figure 1. Displaying resilient characteristics (Individual) predicts vulnerabilities being revealed during stressors (team) via commitment to team goals (Model 1)

Figure 1 shows the role of commitment to team goals between individual ability to demonstrate resilient characteristics and team vulnerabilities being revealed during stressors. According to the model, it is hypothesized that the relationship between individual ability to demonstrate resilient characteristics and team vulnerabilities being revealed during stressors is mediated by commitment to team goals $\left(\mathrm{H}_{1}\right)$. Table displays the parameter estimates of model 1.

Table 4. The parameter estimates of model 1

\begin{tabular}{|c|c|c|c|c|c|c|c|}
\hline Independent & Dependent & $\begin{array}{l}\text { Med/ } \\
\text { Mod }\end{array}$ & $\begin{array}{c}\text { Std. Total Effect } \\
(C I \% 95)\end{array}$ & $\begin{array}{c}\text { Regression Weights } \\
\text { (CI\%95) }\end{array}$ & S.E. & $\begin{array}{c}\text { Std. } \\
\text { Regression }\end{array}$ & $\mathbf{p}$ \\
\hline I-RC & CTG & - & $\begin{array}{c}0,67 \\
(0,54-0,76)\end{array}$ & $\begin{array}{c}0,67 \\
(0,46-0,85)\end{array}$ & 0,04 & 0,67 & 0,000 \\
\hline I-RC & T-VRS & - & $\begin{array}{c}-0,55 \\
(-0,64--0,43)\end{array}$ & $\begin{array}{c}-0,50 \\
(-0,69--0,28)\end{array}$ & 0,09 & $-0,34$ & 0,000 \\
\hline CTG & T-VRS & - & $\begin{array}{c}-0,30 \\
(-0,45--0,17)\end{array}$ & $\begin{array}{c}-0,44 \\
(-0,65--0,25)\end{array}$ & 0,09 & $-0,30$ & 0,000 \\
\hline I-RC & T-VRS & CTG & $\begin{array}{c}-0,20 \\
(-0,33--0,11)\end{array}$ & $\begin{array}{c}-0,30 \\
(-0,48--0,16)\end{array}$ & 0,08 & $-0,20$ & 0,000 \\
\hline
\end{tabular}

CI (\%95) - Bias-corrected percentile method. $p$ is lower than 0,001 for all parameters including std. total effects, regression weights and std. regression weights. 
I-RC predicted CTG positively $\left(R_{1}=0,67, p<0,001\right)$ and T-VRS negatively $\left(R_{2}=-0,34\right)$. CTG negatively predicted T-VRS $\left(\mathrm{R}_{3}=-0,30\right)$. I-RC had negative indirect effect on T-VRS through CTG $\left(R_{1} * R_{2}=-0,20, p<0,001\right)$. The standardized total effect of I-RC on T-VRS was 0,55 . The standardized regression coefficient between I-RC and T-VRS was $-0,55$. CTG has a mediation role between I-RC and T-VRS, indicating that the hypothesis was accepted.

Mediation model 2: Displaying resilient characteristics (team) predicts vulnerabilities being revealed during stressors (individual) via commitment to team goals

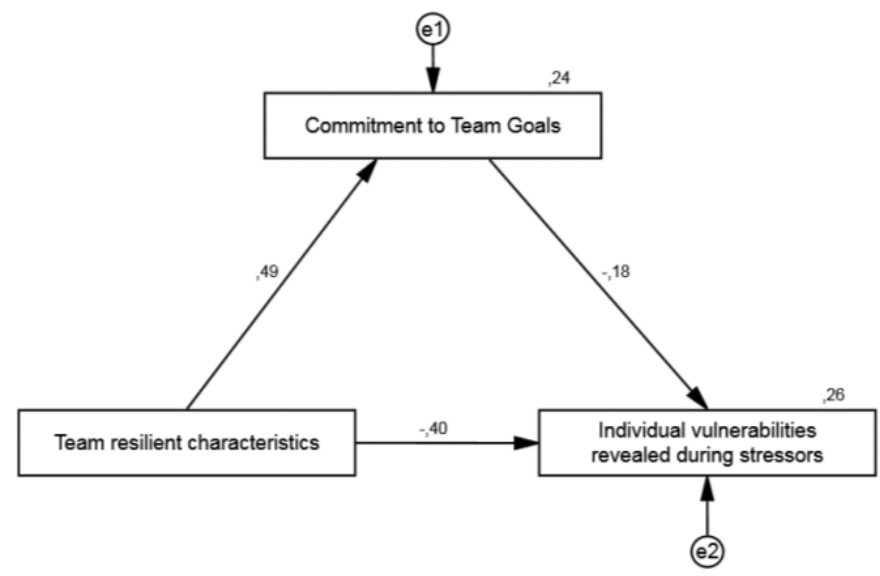

Figure 2. Displaying resilient characteristics (team) predicts vulnerabilities being revealed during stressors (individual) via commitment to team goals (Model 2)

Figure 2 shows the role of commitment to team goals between team ability to demonstrate resilient characteristics and individual vulnerabilities being revealed during stressors. According to the model, it is hypothesized that the relationship between team ability to demonstrate resilient characteristics and individual vulnerabilities being revealed during stressors is mediated by commitment to team goals $\left(\mathrm{H}_{2}\right)$. Table displays the parameter estimates of model 2 .

Table 5. The parameter estimates of model 2

\begin{tabular}{|c|c|c|c|c|c|c|c|}
\hline Independent & Dependent & $\begin{array}{l}\text { Med/ } \\
\text { Mod }\end{array}$ & $\begin{array}{l}\text { Std. Total Effect } \\
\text { (CI\%95) }\end{array}$ & $\begin{array}{l}\text { Regression Weights } \\
\text { (CI \%95) }\end{array}$ & S.E. & $\begin{array}{c}\text { Std. } \\
\text { Regression }\end{array}$ & p \\
\hline T-RC & CTG & - & $\begin{array}{c}0,49 \\
(0,31-0,62)\end{array}$ & $\begin{array}{c}0,41 \\
(0,25-0,59)\end{array}$ & 0,04 & 0,49 & 0,000 \\
\hline T-RC & I-VRS & - & $\begin{array}{c}-0,48 \\
(-0,58--0,37)\end{array}$ & $\begin{array}{c}-0,48 \\
(-0,64-0,32)\end{array}$ & 0,08 & $-0,39$ & 0,000 \\
\hline CTG & I-VRS & - & $\begin{array}{c}-0,17 \\
(-0,29--0,04)\end{array}$ & $\begin{array}{c}-0,25 \\
(-0,43--0,06)\end{array}$ & 0,07 & $-0,17$ & 0,003 \\
\hline T-RC & I-VRS & CTG & $\begin{array}{c}-0,08 \\
(-0,17--0,02)\end{array}$ & $\begin{array}{c}-0,10 \\
(-0,20--0,03)\end{array}$ & 0,04 & $-0,08$ & 0,005 \\
\hline
\end{tabular}

CI (\%95) - Bias-corrected percentile method. $p$ is lower than 0,01 for all parameters including std. total effects, regression weights and std. regression weights. 
T-RC predicted CTG positively $\left(\mathrm{R}_{1}=0,49, \mathrm{p}<0,001\right)$ and I-VRS negatively $\left(\mathrm{R}_{2}=-0,39\right.$, $\mathrm{p}<0,001)$. CTG negatively predicted I-VRS $\left(\mathrm{R}_{3}=-0,17, \mathrm{p}<0,001\right) . \mathrm{T}-\mathrm{RC}$ had a negative indirect impact on I-VRS via CTG $\left(R 1^{*} R_{3}=-0,08, p<0,01\right)$. The standardized total effect of T-RC on IVRS was $-0,48$. The standardized regression coefficient between T-RC and I-VRS was $-0,48$. $\mathrm{H}_{3}$ was accepted since CTG played a mediation role.

Mediation model 3: Displaying resilient characteristics (team) predicts vulnerabilities being revealed during stressors (individual) via commitment to individual goals.

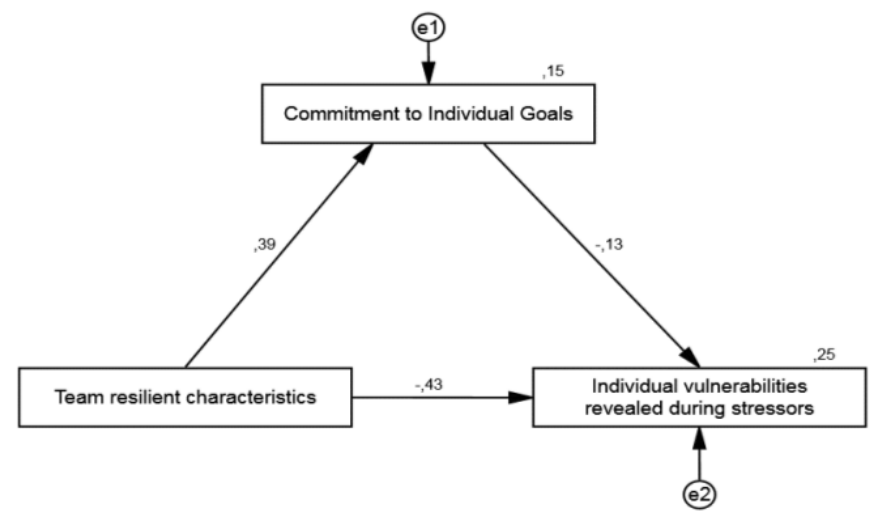

Figure 3. Displaying resilient characteristics (team) predicts vulnerabilities being revealed during stressors (individual) via commitment to individual goals.

Figure 3 presents the role of commitment to individual goals between team ability to demonstrate resilient characteristics and individual vulnerabilities being revealed during stressors. In this model, it was hypothesized that the relationship between team ability to demonstrate resilient characteristics and individual vulnerabilities being revealed during stressors is mediated by commitment to individual goals $\left(\mathrm{H}_{3}\right)$. Table shows the parameter estimates of model 3.

Table 6. The parameter estimates of model 3

\begin{tabular}{|c|c|c|c|c|c|c|c|}
\hline Independent & Dependent & $\begin{array}{c}\text { Med/ } \\
\text { Mod }\end{array}$ & $\begin{array}{c}\text { Std. Total Effect } \\
\text { (CI \%95) }\end{array}$ & $\begin{array}{c}\text { Regression Weights } \\
\text { (CI\%95) }\end{array}$ & S.E. & $\begin{array}{c}\text { Std. } \\
\text { Regression }\end{array}$ & $\mathbf{p}$ \\
\hline T-RC & CIG & - & $\begin{array}{c}0,38 \\
(0,21-0,53)\end{array}$ & $\begin{array}{c}0,35 \\
(0,18-0,53)\end{array}$ & 0,05 & 0,38 & 0,000 \\
\hline T-RC & I-VRS & - & $\begin{array}{c}-0,48 \\
(-0,58--0,37)\end{array}$ & $\begin{array}{c}-0,52 \\
(-0,66--0,39)\end{array}$ & 0,06 & $-0,43$ & 0,000 \\
\hline CIG & I-VRS & - & $\begin{array}{c}-0,12 \\
(-0,22--0,02)\end{array}$ & $\begin{array}{c}-0,17 \\
(-0,30--0,03)\end{array}$ & 0,07 & $-0,12$ & 0,022 \\
\hline T-RC & I-VRS & CIG & $\begin{array}{c}-0,04 \\
(-0,10--0,01)\end{array}$ & $\begin{array}{c}-0,060 \\
(-0,12--0,01)\end{array}$ & 0,02 & $-0,04$ & 0,008 \\
\hline
\end{tabular}

CI (\%95) - Bias-corrected percentile method. $p$ is lower than 0,01 for all parameters including std. total effects, regression weights and std. regression weights.

T-RC predicted CIG positively $(\mathrm{R} 1=0,38, \mathrm{p}<0,001)$ and I-VRS negatively $(\mathrm{R} 2=-0,43$, $\mathrm{p}<0,001)$. CIG negatively predicted I-VRS $(R 3=-0,12, \mathrm{p}<0,05) . \mathrm{T}-\mathrm{RC}$ had a negative indirect 
effect on I-VRS via CIG (R1*R3=-0,04, p<0,01). The standardized total effect of T-RC on IVRS was $-0,48$. The standardized regression coefficient between T-RC and I-VRS was $-0,48$. $\mathrm{H}_{4}$ was accepted because CIG played a mediation role.

\section{Decreasing Mediation Models (Two Outcome Analyses)}

Mediation model 4: Displaying resilient characteristics (team) predicts vulnerabilities being revealed during stressors (team and individual) via commitment to team goals.

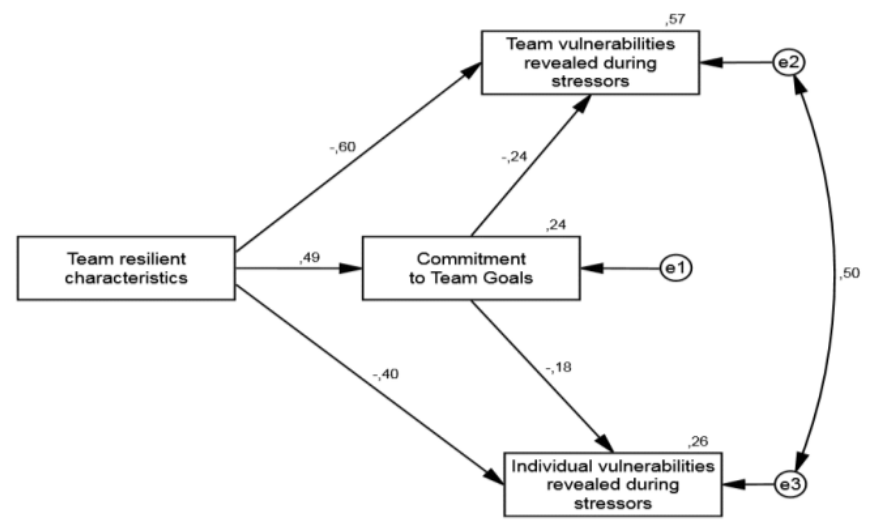

Figure 5. Displaying resilient characteristics (team) predicts vulnerabilities being revealed during stressors (team and individual) via commitment to team goals

Figure 5 shows the role of commitment to team goals between team ability to demonstrate resilient characteristics, team and individual vulnerabilities being revealed during stressors. The model proposes that the relationship between team ability to demonstrate resilient characteristics, team and individual vulnerabilities being revealed during stressors is mediated by commitment to team goals $\left(\mathrm{H}_{4}\right)$. Table shows the parameter estimates.

Table 7. The parameter estimates of model 4

\begin{tabular}{|c|c|c|c|c|c|c|c|}
\hline Independent & Dependent & $\begin{array}{r}\text { Med/ } \\
\text { Mod }\end{array}$ & $\begin{array}{c}\text { Std. Total Effect } \\
(C I \% 95) \\
\end{array}$ & $\begin{array}{c}\text { Regression Weights } \\
\text { (CI\%95) }\end{array}$ & S.E. & $\begin{array}{c}\text { Std. } \\
\text { Regression } \\
\end{array}$ & $\mathbf{p}$ \\
\hline $\mathrm{T}-\mathrm{RC}$ & CTG & - & $\begin{array}{c}0,49 \\
(0,31-0,62)\end{array}$ & $\begin{array}{c}0,41 \\
(0,25-0,59)\end{array}$ & 0,04 & 0,49 & 0,000 \\
\hline CTG & T-VRS & - & $\begin{array}{c}-0,24 \\
(-0,41--0,08)\end{array}$ & $\begin{array}{c}-0,35 \\
(-0,59--0,13)\end{array}$ & 0,06 & $-0,24$ & 0,000 \\
\hline CTG & I-VRS & - & $\begin{array}{c}-0,17 \\
(-0,29--0,04)\end{array}$ & $\begin{array}{c}-0,25 \\
(-0,43--0,06)\end{array}$ & 0,08 & $-0,17$ & 0,003 \\
\hline T-RC & T-VRS & - & $\begin{array}{c}-0,72 \\
(-0,79--0,62)\end{array}$ & $\begin{array}{c}-0,73 \\
(-0,86--0,59)\end{array}$ & 0,05 & $-0,60$ & 0,000 \\
\hline T-RC & I-VRS & - & $\begin{array}{c}-0,48 \\
(-0,58--0,37)\end{array}$ & $\begin{array}{c}-0,48 \\
(-0,64--0,32)\end{array}$ & 0,07 & $-0,39$ & 0,000 \\
\hline T-RC & T-VRS & CTG & $\begin{array}{c}-0,08 \\
(-0,17--0,05)\end{array}$ & $\begin{array}{c}-0,10 \\
(-0,20--0,06)\end{array}$ & 0,03 & $-0,08$ & 0,000 \\
\hline T-RC & I-VRS & CTG & $\begin{array}{c}-0,11 \\
(-0,20--0,02)\end{array}$ & $\begin{array}{c}-0,14 \\
(-0,25--0,03)\end{array}$ & 0,03 & $-0,11$ & 0,005 \\
\hline
\end{tabular}

CI (\%95) - Bias-corrected percentile method. $p$ is lower than 0,01 for all parameters including std. total effects, regression weights and std. regression weights. 
T-RC predicted CTG positively (R1=0,49, p<0,001), T-VRS (R2=-0,60, p<0,001) and IVRS negatively $(R 3=-0,39, p<0,001)$. CTG negatively predicted T-VRS $(R 4=-0,24, p<0,001)$ and I-VRS (R5 $=-0,17, \mathrm{p}<0,01)$. T-RC had negative indirect effects on T-VRS (R1*R4=-0,08, $\mathrm{p}<0,001)$ and I-VRS (R1*R5=-0,011). The standardized total effects of T-RC on T-VRS were $-0,72$ while the one on I-VRS was $-0,48$. The standardized regression coefficient between $T-$ $\mathrm{RC}$ and T-VRS was $-0,72$. The standardized regression coefficient between T-RC and I-VRS was $-0,48$. According to these results, $\mathrm{H}_{4}$ was accepted.

Mediation model 5: Displaying resilient characteristics (team) predicts vulnerabilities being revealed during stressors (team and individual) via commitment to individual goals.

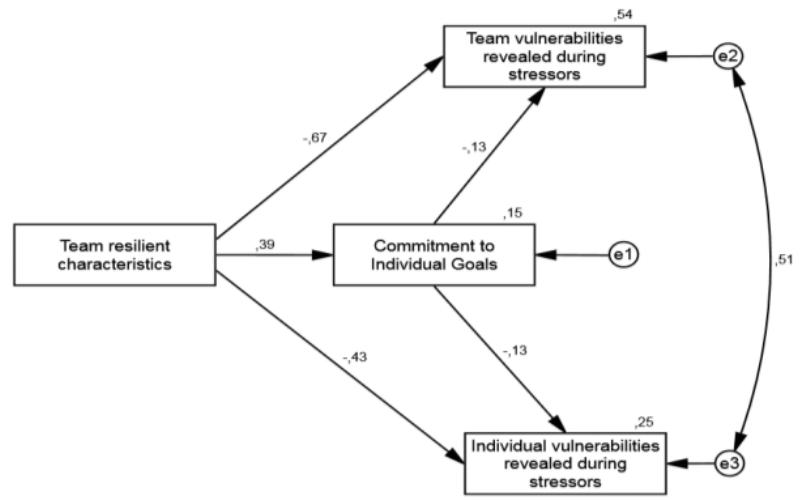

Figure 6. Displaying resilient characteristics (team) predicts vulnerabilities being revealed during stressors (team and individual) via commitment to individual goals

Figure 6 presents the role of commitment to individual goals between team ability to demonstrate resilient characteristics, team and individual vulnerabilities being revealed during stressors. The model proposes that the relationship between team ability to demonstrate resilient characteristics, team and individual vulnerabilities being revealed during stressors is mediated by commitment to individual goals $\left(\mathrm{H}_{5}\right)$. Table shows the parameter estimates.

Table 8. The parameter estimates of model 5

\begin{tabular}{|c|c|c|c|c|c|c|c|}
\hline Independent & Dependent & Med/Mod & $\begin{array}{l}\text { Std. Total Effect } \\
\text { (CI \%95) }\end{array}$ & $\begin{array}{c}\text { Regression Weights } \\
\text { (CI\%95) }\end{array}$ & S.E. & $\begin{array}{c}\text { Std. } \\
\text { Regression }\end{array}$ & $\mathbf{p}$ \\
\hline T-RC & CIG & - & $\begin{array}{c}0,38 \\
(0,21-0,53)\end{array}$ & $\begin{array}{c}0,35 \\
(0,18-0,53)\end{array}$ & 0,05 & 0,38 & 0,000 \\
\hline CIG & T-VRS & - & $\begin{array}{c}-0,12 \\
(-0,25--0,02)\end{array}$ & $\begin{array}{c}-0,17 \\
(-0,35--0,03)\end{array}$ & 0,05 & $-0,12$ & 0,003 \\
\hline CIG & I-VRS & - & $\begin{array}{c}-0,12 \\
(-0,22--0,02)\end{array}$ & $\begin{array}{c}-0,17 \\
(-0,30--0,03)\end{array}$ & 0,07 & $-0,12$ & 0,022 \\
\hline T-RC & T-VRS & - & $\begin{array}{c}-0,72 \\
(-0,79--0,62)\end{array}$ & $\begin{array}{c}-0,82 \\
(-0,92--0,63)\end{array}$ & 0,05 & $-0,67$ & 0,000 \\
\hline T-RC & I-VRS & - & $\begin{array}{c}-0,48 \\
(-0,58--0,37)\end{array}$ & $\begin{array}{c}-0,52 \\
(-0,52--0,66)\end{array}$ & 0,06 & $-0,43$ & 0,000 \\
\hline T-RC & T-VRS & CIG & $\begin{array}{c}-0,04 \\
(-0,11--0,01)\end{array}$ & $\begin{array}{c}-0,06 \\
(-0,14--0,1)\end{array}$ & 0,03 & $-0,04$ & 0,007 \\
\hline T-RC & I-VRS & CIG & $\begin{array}{c}-0,04 \\
(-0,10--0,01)\end{array}$ & $\begin{array}{c}-0,06( \\
-0,12--0,01)\end{array}$ & 0,02 & $-0,04$ & 0,008 \\
\hline
\end{tabular}

CI (\%95) - Bias-corrected percentile method. $p$ is lower than 0,01 for all parameters including std. total effects, regression weights and std. regression weights. 
T-RC predicted CIG positively ( $R 1=0,38, \mathrm{p}<0,001)$, T-VRS (R2=-0,67, $\mathrm{p}<0,001)$ and IVRS negatively $(R 3=-0,43, p<0,001)$. CIG negatively predicted T-VRS $(R 4=-0,12, p<0,01)$ and I-VRS (R5=-0,12, p<0,05). T-RC had negative indirect effects on T-VRS (R1*R4=-0,04, $\mathrm{p}<0,001)$ and I-VRS $(\mathrm{R} 1 * \mathrm{R} 5=-0,04)$. The standardized total effects of T-RC on T-VRS were 0,72 while the one on I-VRS was $-0,48$. The standardized regression coefficient between $\mathrm{T}$ $\mathrm{RC}$ and T-VRS was $-0,72$. The standardized regression coefficient between T-RC and I-VRS was $-0,48$. According to these results, $\mathrm{H}_{5}$ was accepted.

Mediation model 6: Commitment to team goals predicts vulnerabilities being revealed during stressors (team and individual) via displaying resilient characteristics (team).

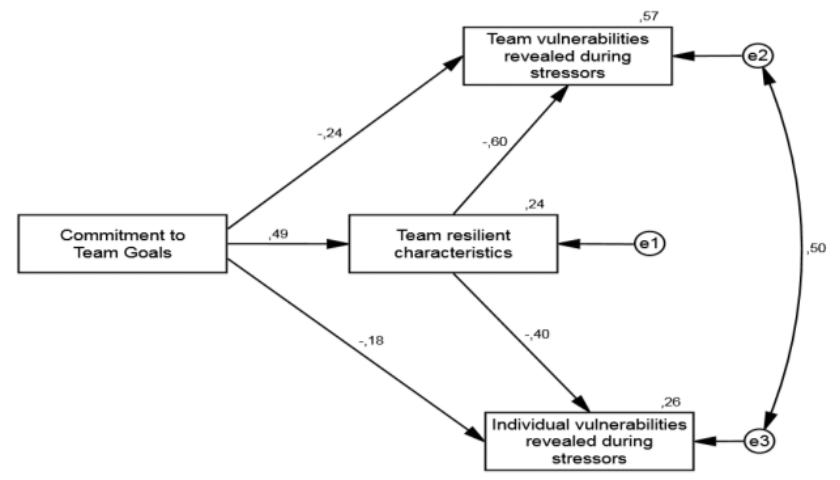

Figure 7. Commitment to team goals predicts vulnerabilities being revealed during stressors (team and individual) via displaying resilient characteristics (team)

Figure 7 shows the role of team ability to demonstrate resilient characteristics between commitment to team goals, team and individual vulnerabilities being revealed during stressors. The model proposes that team ability to demonstrate team resilient characteristics mediates the relationship between commitment to team goals, team and individual vulnerabilities being revealed during stressors $\left(\mathrm{H}_{6}\right)$. Table displays the parameter estimates of model 6.

Table 9. The parameter estimates of model 6

\begin{tabular}{|c|c|c|c|c|c|c|c|}
\hline Independent & Dependent & $\begin{array}{c}\text { Med/ } \\
\text { Mod }\end{array}$ & $\begin{array}{c}\text { Std. Total Effect } \\
(C I \% 95)\end{array}$ & $\begin{array}{c}\text { Regression Weights } \\
(C I \% 95)\end{array}$ & S.E. & $\begin{array}{c}\text { Std. } \\
\text { Regression } \\
\end{array}$ & $\mathbf{p}$ \\
\hline CTG & T-RC & & $\begin{array}{c}0,49 \\
(0,31-0,62)\end{array}$ & $\begin{array}{c}0,53 \\
(0,35-0,74)\end{array}$ & 0,06 & 0,49 & 0,000 \\
\hline T-RC & T-VRS & & $\begin{array}{c}-0,60 \\
(-0,72--0,46)\end{array}$ & $\begin{array}{c}-0,73 \\
(-0,86--0,59)\end{array}$ & 0,05 & $-0,60$ & 0,000 \\
\hline T-RC & I-VRS & & $\begin{array}{c}-0,39 \\
(-0,52--0,27)\end{array}$ & $\begin{array}{c}-0,48 \\
(-0,64--0,32)\end{array}$ & 0,07 & $-0,39$ & 0,000 \\
\hline CTG & T-VRS & & $\begin{array}{c}-0,53 \\
(-0,63--0,41)\end{array}$ & $\begin{array}{c}-0,35 \\
(-0,59--0,13)\end{array}$ & 0,06 & $-0,24$ & 0,000 \\
\hline CTG & I-VRS & & $\begin{array}{c}-0,37 \\
(-0,48--0,25)\end{array}$ & $\begin{array}{c}-0,25 \\
(-0,43--0,06)\end{array}$ & 0,08 & $-0,17$ & 0,003 \\
\hline CTG & T-VRS & $\mathrm{T}-\mathrm{RC}$ & $\begin{array}{c}-0,29 \\
(-0,42--0,16)\end{array}$ & $\begin{array}{c}-0,43 \\
(-0,62--0,23)\end{array}$ & 0,06 & $-0,29$ & 0,001 \\
\hline CTG & I-VRS & T-RC & $\begin{array}{c}-0,19 \\
(-0,29--0,12)\end{array}$ & $\begin{array}{c}-0,28 \\
(-0,43--0,17)\end{array}$ & 0,04 & $-0,19$ & 0,000 \\
\hline
\end{tabular}

CI (\%95) - Bias-corrected percentile method. $p$ is lower than 0,01 for all parameters including std. total effects, regression weights and std. regression weights. 
CTG predicted $\mathrm{T}-\mathrm{RC}$ positively $(\mathrm{R} 1=0,49, \mathrm{p}<0,001)$ and negatively $\mathrm{T}-\mathrm{VRS}(\mathrm{R} 2=-0,24$, $\mathrm{p}<0,001)$ and I-VRS $(\mathrm{R} 3=-0,17, \mathrm{p}<0,01)$. T-RC negatively predicted $\mathrm{T}$-VRS $(\mathrm{R} 4=-0,60$, $\mathrm{p}<0,001)$ and I-VRS (R5 $=-0,39, \mathrm{p}<0,001)$. CTG had negative indirect effects on T-VRS $(R 1 * R 4=-0,29, p<0,01)$ and I-VRS (R1*R5 $=-0,19, p<0,001)$. The standardized total effects of CTG on T-VRS was $-0,53$. The standardized total effects of CTG on I-VRS was $-0,37$. The standardized regression coefficient between CTG and T-VRS was $-0,53$. The standardized regression coefficient between CTG and T-IRS was $-0,37$. According to these results, $\mathrm{H}_{6}$ was accepted.

\section{Increasing Mediation Models (One Mediator Analyses)}

Mediation model 7: Commitment to team goals predicts displaying resilient characteristics (Individual) via commitment to individual goals.

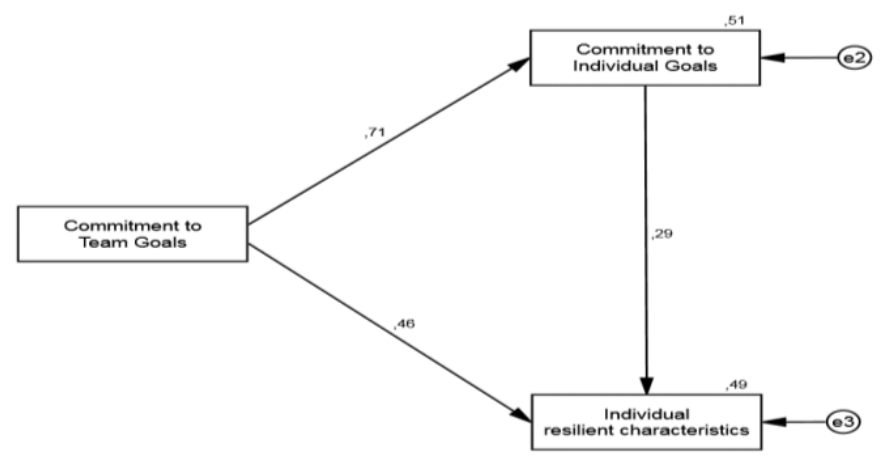

Figure 8. Commitment to team goals predicts displaying resilient characteristics (Individual) via commitment to individual goals

Figure 8 presents the role of commitment to individual goals between commitment to team goals and individual ability to demonstrate resilient characteristics. The model proposes that commitment to individual goals mediates the relationship between commitment to team goals and individual ability to demonstrate resilient characteristics. Table shows the parameter estimates of model 7.

Table 10. The parameter estimates of model 7

\begin{tabular}{|c|c|c|c|c|c|c|c|}
\hline Independent & Dependent & $\begin{array}{l}\text { Med/ } \\
\text { Mod }\end{array}$ & $\begin{array}{c}\text { Std. Total Effect } \\
(C I \% 95)\end{array}$ & $\begin{array}{c}\text { Regression Weights } \\
\text { (CI\%95) }\end{array}$ & S.E. & $\begin{array}{c}\text { Std. } \\
\text { Regression }\end{array}$ & $\mathbf{p}$ \\
\hline CTG & CIG & & $\begin{array}{c}0,71 \\
(0,56-0,81)\end{array}$ & $\begin{array}{c}0,77( \\
0,64-0,87)\end{array}$ & 0,04 & 0,71 & 0,000 \\
\hline CTG & I-RC & & $\begin{array}{c}0,67 \\
(0,54-0,76)\end{array}$ & $\begin{array}{c}0,46 \\
(0,30-0,58)\end{array}$ & 0,06 & 0,46 & 0,000 \\
\hline CIG & I-RC & & $\begin{array}{c}0,29 \\
(0,15-0,45)\end{array}$ & $\begin{array}{c}0,26 \\
(0,14-0,43)\end{array}$ & 0,05 & 0,29 & 0,000 \\
\hline CTG & I-RC & CIG & $\begin{array}{c}0,20 \\
(0,11-0,35)\end{array}$ & $\begin{array}{c}0,20 \\
(0,11-0,35)\end{array}$ & 0,05 & 0,20 & 0,000 \\
\hline
\end{tabular}

CI (\%95) - Bias-corrected percentile method. $p$ is lower than 0,01 for all parameters including std. total effects, regression weights and std. regression weights. 
CTG positively predicted CIG (R1=0,71, $\mathrm{p}<0,001)$ and I-RC $(\mathrm{R} 2=0,46, \mathrm{p}<0,001)$. CIG also positively predicted I-RC $(R 3=0,29, p<0,001)$. CTG has a positive indirect effect on I-RC (R1*R3=0,20, p<0,001). The standardized total effects of CTG on I-RC was 0,67. The standardized regression coefficient between CTG and I-RC was 0,67. $\mathrm{H}_{7}$ was accepted.

Mediation model 8: Commitment to individual goals predicts displaying resilient characteristics (Individual) via commitment to team goals.

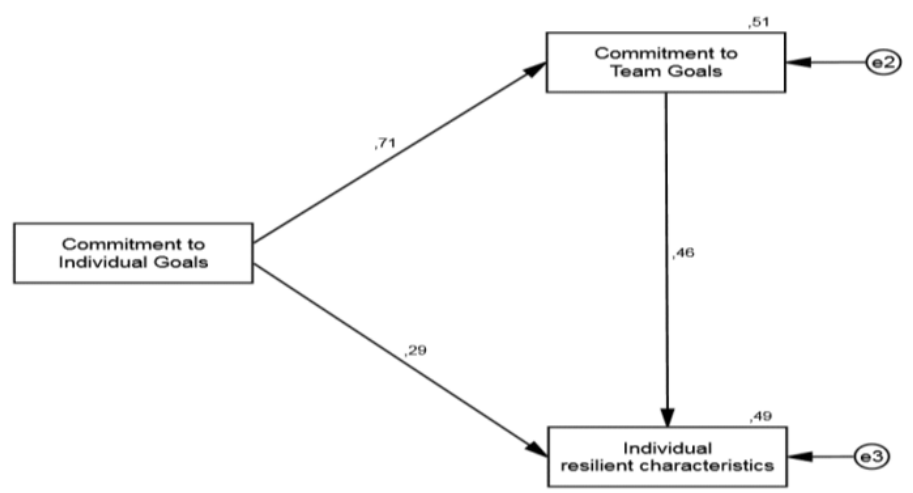

Figure 9. Commitment to individual goals predicts displaying resilient characteristics (Individual) via commitment to team goals

Figure 9 shows the role of commitment to team goals between commitment to individual goals and individual ability to demonstrate resilient characteristics. The model proposes that commitment to team goals mediates the relationship between commitment to individual goals and individual ability to demonstrate resilient characteristics. Table shows the parameter estimates of model 32.

Table 11. The parameter estimates of model 8

\begin{tabular}{|c|c|c|c|c|c|c|c|}
\hline Independent & Dependent & $\begin{array}{l}\text { Med/ } \\
\text { Mod }\end{array}$ & $\begin{array}{l}\text { Std. Total Effect } \\
\text { (CI \%95) }\end{array}$ & $\begin{array}{l}\text { Regression Weights } \\
\text { (CI \%95) }\end{array}$ & S.E. & $\begin{array}{c}\text { Std. } \\
\text { Regression }\end{array}$ & $\mathbf{p}$ \\
\hline CIG & CTG & & $\begin{array}{c}0,71 \\
(0,56-0,81)\end{array}$ & $\begin{array}{c}0,65 \\
(0,45-0,80)\end{array}$ & 0,03 & 0,71 & 0,000 \\
\hline CIG & I-RC & & $\begin{array}{c}0,62( \\
0,47-0,72)\end{array}$ & $\begin{array}{c}0,26( \\
0,14-0,43)\end{array}$ & 0,05 & 0,29 & 0,000 \\
\hline CTG & I-RC & & $\begin{array}{c}0,46 \\
(0,29-0,60)\end{array}$ & $\begin{array}{c}0,46 \\
(0,30-0,58)\end{array}$ & 0,06 & 0,46 & 0,000 \\
\hline CIG & I-RC & CTG & $\begin{array}{c}0,33 \\
(0,20-0,47)\end{array}$ & $\begin{array}{c}0,30 \\
(0,19-0,42)\end{array}$ & 0,07 & 0,33 & 0,000 \\
\hline
\end{tabular}

CI (\%95) - Bias-corrected percentile method. $p$ is lower than 0,001 for all parameters including std. total effects, regression weights and std. regression weights.

CIG positively predicted CTG $(R 1=0,71, \mathrm{p}<0,001)$ and $\mathrm{I}-\mathrm{RC}(\mathrm{R} 2=0,29, \mathrm{p}<0,001)$. CTG also positively predicted I-RC $(R 3=0,46, p<0,001)$. CIG has a positive indirect effect on I-RC $(\mathrm{R} 1 * \mathrm{R} 3=0,33, \mathrm{p}<0,001)$. The standardized total effect of CIG on I-RC was 0,62 . The standardized regression coefficient between CTG and I-RC was 0,62. $\mathrm{H}_{8}$ was accepted. 
Mediation model 9: Resilient characteristics (team) predicts resilient characteristics (individual) via commitment to team goals

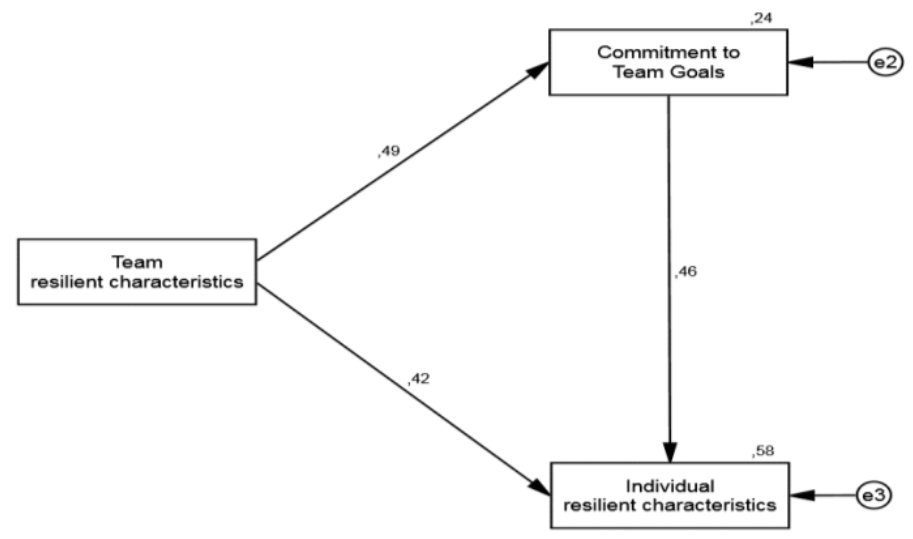

Figure 10. Resilient characteristics (team) predicts resilient characteristics (individual) via commitment to team goals.

Figure 10 displays the role of commitment to team goals between team ability to demonstrate resilient characteristics and individual ability to demonstrate resilient characteristics. The model hypothesizes that commitment to team goals mediates the relationship between team ability to demonstrate resilient characteristics and individual ability to demonstrate resilient characteristics. Table shows the parameter estimates of model 9.

Table 12. The parameter estimates of model 9

\begin{tabular}{|c|c|c|c|c|c|c|c|}
\hline Independent & Dependent & $\begin{array}{l}\text { Med/ } \\
\text { Mod }\end{array}$ & $\begin{array}{l}\text { Std. Total Effect } \\
\text { (CI\%95) }\end{array}$ & $\begin{array}{c}\text { Regression Weights } \\
\text { (CI\%95) }\end{array}$ & S.E. & $\begin{array}{c}\text { Std. } \\
\text { Regression }\end{array}$ & $\mathbf{p}$ \\
\hline T-RC & CTG & & $\begin{array}{c}0,49 \\
(0,31-0,62)\end{array}$ & $\begin{array}{c}0,41 \\
(0,25-0,59)\end{array}$ & 0,04 & 0,49 & 0,000 \\
\hline T-RC & $\mathrm{I}-\mathrm{RC}$ & & $\begin{array}{c}0,64( \\
0,53-0,74)\end{array}$ & $\begin{array}{c}0,35 \\
(0,34-0,54)\end{array}$ & 0,03 & 0,42 & 0,000 \\
\hline CTG & $\mathrm{I}-\mathrm{RC}$ & & $\begin{array}{c}0,46 \\
(0,30-0,59)\end{array}$ & $\begin{array}{c}0,46 \\
(0,25-0,47)\end{array}$ & 0,04 & 0,46 & 0,000 \\
\hline $\mathrm{T}-\mathrm{RC}$ & I-RC & CTG & $\begin{array}{c}0,22 \\
(0,13-0,34)\end{array}$ & $\begin{array}{c}0,19 \\
(0,11-0,29)\end{array}$ & 0,04 & 0,22 & 0,000 \\
\hline
\end{tabular}

CI (\%95) - Bias-corrected percentile method. $p$ is lower than 0,001 for all parameters including std. total effects, regression weights and std. regression weights.

T-RC positively predicted CTG $(R 1=0,49, p<0,001)$ and I-RC (R2=0,42, $p<0,001)$. CTG positively predicted I-RC $(\mathrm{R} 3=0,46, \mathrm{p}<0,001)$. The standardized total effect of $\mathrm{T}-\mathrm{RC}$ on $\mathrm{I}-\mathrm{RC}$ was 0,64 . T-RC had positive indirect effect on I-RC (R1*R3=0,228, $p<0,001)$. The standardized regression coefficient between T-RC and I-RC was 0,64. $\mathrm{H}_{9}$ was accepted. 
Mediation model 10: Resilient characteristics (team) predicts resilient characteristics (individual) via commitment to individual goals.

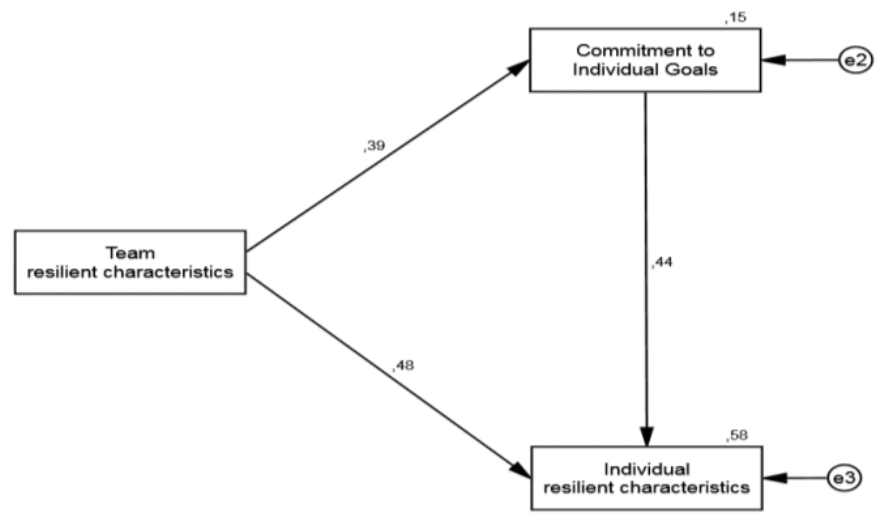

Figure 11. Resilient characteristics (team) predicts resilient characteristics (individual) via commitment to individual goals.

Figure 11 presents the role of commitment to individual goals between team ability to demonstrate resilient characteristics and individual ability to demonstrate resilient characteristics. The model hypothesizes that commitment to individual goals mediates the relationship between team ability to demonstrate resilient characteristics and individual ability to demonstrate resilient characteristics. Table shows the parameter estimates of model 10 .

Table 13. The parameter estimates of model 10

\begin{tabular}{|c|c|c|c|c|c|c|c|}
\hline Independent & Dependent & $\begin{array}{l}\text { Med/ } \\
\text { Mod }\end{array}$ & $\begin{array}{l}\text { Std. Total Effect } \\
\text { (CI \%95) }\end{array}$ & $\begin{array}{c}\text { Regression Weights } \\
\text { (CI\%95) }\end{array}$ & S.E. & $\begin{array}{c}\text { Std. } \\
\text { Regression }\end{array}$ & $\mathbf{p}$ \\
\hline T-RC & $\begin{array}{l}\text { CIG } \\
\end{array}$ & & $\begin{array}{c}0,38 \\
(0,21-0,53)\end{array}$ & $\begin{array}{c}0,35 \\
(0,18-0,53)\end{array}$ & 0,05 & 0,38 & 0,000 \\
\hline $\mathrm{T}-\mathrm{RC}$ & I-RC & & $\begin{array}{c}0,64 \\
(0,53-0,74)\end{array}$ & $\begin{array}{c}0,40 \\
(0,31-0,49)\end{array}$ & 0,03 & 0,48 & 0,000 \\
\hline CIG & I-RC & & $\begin{array}{c}0,43 \\
(0,33-0,53)\end{array}$ & $\begin{array}{c}0,40 \\
(0,30-0,49)\end{array}$ & 0,03 & 0,43 & 0,000 \\
\hline T-RC & I-RC & CIG & $\begin{array}{c}0,16 \\
(0,08-0,26)\end{array}$ & $\begin{array}{c}0,14 \\
(0,06-0,22)\end{array}$ & 0,04 & 0,16 & 0,000 \\
\hline
\end{tabular}

CI (\%95) - Bias-corrected percentile method. $p$ is lower than 0,001 for all parameters including std. total effects, regression weights and std. regression weights.

T-RC positively predicted CIG ( $R 1=0,38, p<0,001)$ and I-RC $(R 2=0,48, p<0,001)$. CIG positively predicted I-RC $(R 3=0,43, p<0,001)$. The standardized total effect of T-RC on I-RC was 0,64 . T-RC had positive indirect effect on I-RC (R1*R3=0,16, p<0,001). The standardized regression coefficient between T-RC and I-RC was 0,64 . $\mathrm{H}_{10}$ was accepted. 


\section{Increasing Mediation Models (Two Mediators Analyses)}

Mediation model 11: Resilient characteristics (team) predicts resilient characteristics (individual) via commitment to team and individual goals.

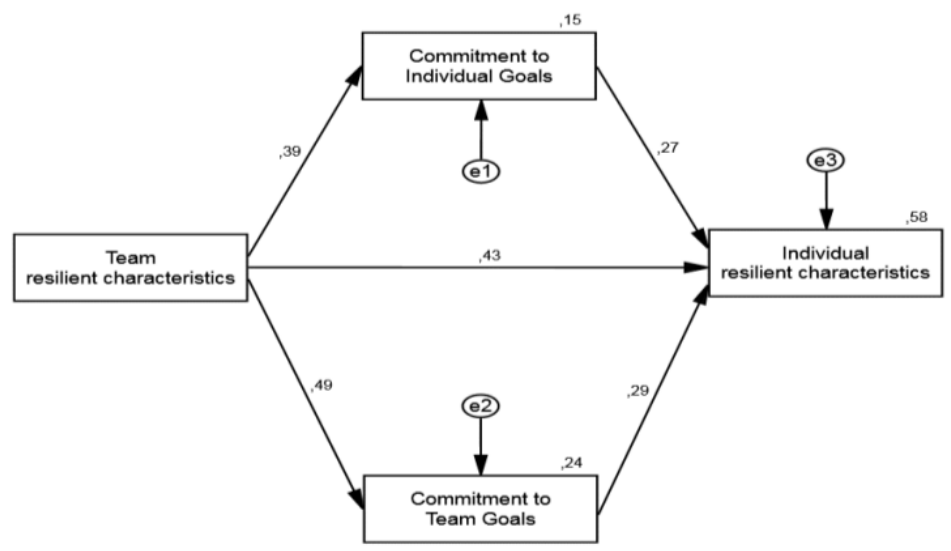

Figure 12. Resilient characteristics (team) predicts resilient characteristics (individual) via commitment to team and individual goals

Figure 12 displays the roles of commitment to team and individual goals between team and individual abilities to demonstrate resilient characteristics. The model hypothesized that commitment to team and individual goals mediate the relationship between team and individual abilities to demonstrate resilient characteristics. Table shows the parameter estimates of model 11.

Table 14. The parameter estimates of model 11

\begin{tabular}{|c|c|c|c|c|c|c|c|}
\hline Independent & Dependent & $\begin{array}{l}\text { Med/ } \\
\text { Mod }\end{array}$ & $\begin{array}{l}\text { Std. Total Effect } \\
\text { (CI\%95) }\end{array}$ & $\begin{array}{c}\text { Regression Weights } \\
\text { (CI\%95) }\end{array}$ & S.E. & $\begin{array}{c}\text { Std. } \\
\text { Regression }\end{array}$ & p \\
\hline T-RC & CIG & & $\begin{array}{c}0,38 \\
(0,21-0,53)\end{array}$ & $\begin{array}{c}0,35 \\
(0,18-0,53)\end{array}$ & 0,050 & 0,38 & 0,000 \\
\hline $\mathrm{T}-\mathrm{RC}$ & CTG & & $\begin{array}{c}0,49 \\
(0,31-0,62)\end{array}$ & $\begin{array}{c}0,41 \\
(0,25-0,59)\end{array}$ & 0,043 & 0,49 & 0,000 \\
\hline $\mathrm{T}-\mathrm{RC}$ & $\mathrm{I}-\mathrm{RC}$ & & $\begin{array}{c}0,67 \\
(0,55-0,76)\end{array}$ & $\begin{array}{c}0,34 \\
(0,24-0,45)\end{array}$ & 0,035 & 0,42 & 0,000 \\
\hline CIG & $\mathrm{I}-\mathrm{RC}$ & & $\begin{array}{c}0,27 \\
(0,16-0,38)\end{array}$ & $\begin{array}{c}0,24 \\
(0,14-0,35)\end{array}$ & 0,048 & 0,27 & 0,000 \\
\hline CTG & $\mathrm{I}-\mathrm{RC}$ & & $\begin{array}{c}0,29 \\
(0,12-0,46)\end{array}$ & $\begin{array}{c}0,27 \\
(0,12-0,40)\end{array}$ & 0,055 & 0,29 & 0,000 \\
\hline${ }^{* *} \mathrm{~T}-\mathrm{RC}$ & $\mathrm{I}-\mathrm{RC}$ & CIG & 0,10 & $\begin{array}{c}0,08 \\
(0,03-0,15)\end{array}$ & 0,029 & 0,10 & 0,000 \\
\hline${ }^{*}$ T $\mathrm{T}-\mathrm{RC}$ & $\mathrm{I}-\mathrm{RC}$ & CTG & 0,14 & $\begin{array}{c}0,11 \\
(0,05-0,20)\end{array}$ & 0,037 & 0,14 & 0,000 \\
\hline
\end{tabular}

*CI (\%95) - Bias-corrected percentile method. $p$ is lower than 0,01 for all parameters including std. total effects, regression weights and std. regression weights.

**Indirect effects were calculated by using user-defined estimands to see the individual indirect effects of paths. 
T-RC positively predicted CIG (R1=0,38, $\mathrm{p}<0,001), \mathrm{CTG}(\mathrm{R} 2=0,49)$, and I-RC $(\mathrm{R} 3=0,42$, $\mathrm{p}<0,001)$. CIG positively predicted I-RC $(\mathrm{R} 4=0,27, \mathrm{p}<0,001)$ and CTG positively predicted I$\mathrm{RC}(\mathrm{R} 5=0,29, \mathrm{p}<0,001)$. The standardized total effect of T-RC on I-RC was $0,67 . \mathrm{T}-\mathrm{RC}$ had positive indirect effect on I-RC via CIG $(R 1 * R 4=0,10, p<0,001)$ and via CTG $(R 2 * R 5=0,14$, $\mathrm{p}<0,001)$. The standardized regression coefficient between T-RC and I-RC was $0,64 . \mathrm{H}_{11}$ was accepted.

\section{Discussion}

This paper contributes to the sport psychology literature by examining the role of goal commitment in decreasing vulnerabilities and increasing resilient characteristics in team athletes. To conduct this study, we proposed mediation models including individual and team commitment as mediators and predictors to see the impacts on team resilience. Before the mediation analysis, there was an important problem to assess individual resilience perception in team athletes, which we solved by adapting team resilience inventory by analyzing its content and construct validity. For content validity, the indexes were found to be appropriate (Lynn, 1986; Polit \& Beck, 2006; Waltz \& Bausell, 1981). The correlation analysis revealed that revised version of team resilience measurement into individual-level measurement was a different measurement even it was an adapted version of team resilience measurement. After meeting the prerequisites to run mediation analysis (Harrington, 2009), we analyzed the direct and indirect effects of goal commitment on team resilience. Researchers reported three stressor categories sport performers may encounter including competitive performance, the sport organization in within which the athletes operate, and personal "nonsporting" life evets (Sarkar \& Fletcher, 2014).

The results supported our hypothesis that goal commitment can be considered as one of the antecedents of resilience at both individual and team levels. Studies showed that commitment is an important indicator of resilience in sports context (Fasey, Sarkar, Wagstaff \& Johnston, 2021; Kegelaers, Wylleman, Blijlevens, Boonstoppel \& Hendriks, 2020; Morgan, Fletcher \& Sarkar, 2019), however, these studies focused on the different aspects of commitment (Sarkar \& Fletcher, 2014). This study provides critical results to understand the process of developing team resilience in sport through goal commitment.

When faced with obstacles, being committed to collective goals enables group member to reach the goal by keeping them to withstand these setbacks. Goal acceptance becomes prominent when the difficulty of goals increases (Erez \& Zidon; 1984; Hollenbeck \& Klein, 1987), in this condition, athletes will start to look for dynamics from the members of the team to accept or reach to these difficult goals. At this point, a collective goal awareness is formed, and the common goals of the team can turn into individual goals of the members. Adherence to these goals increases the capacity to cope with adversity and thus resilience.

Goal commitment has a critical role in determining performance (Hollenbeck \& Klein, 1987). Goal commitment is high when the individual is highly motivated and determined to achieve the goal. Goal commitment increases actual and predicted performance (Riedel, 
Nebeker \& Cooper, 1988). Locke, Frederick, Buckner and Bobko (1984) found that commitment was not related with the performance of those with assigned goals. Therefore, the fact that both team goals and individual goals are externally assigned or determined by the athlete, in other words, the way the goal is set has little relation with performance. It is commitment to these goals linked to performance. The results of this research also showed that goal commitment, which expresses the determination in striving for a goal, encourages the tendency to show resilience, which is explained as not giving up in the face of the difficulties encountered in this process. This research, as a theoretical study that provides an explanation for resilience research in sports from the perspective of goal commitment, revealed the role of goals and commitment to these goals in gaining resilience.

\section{Conclusion}

This study answered two important questions. The first question was what the role of athletes' commitment to team and individual goals is to decrease the vulnerabilities when encountered stressors. It is clearly revealed that goal commitment plays a vital role to decrease vulnerabilities when faced with stressors. It has predictive and mediator impact on the vulnerabilities. The second question was what the role of athletes' commitment to team and individual goals is to increase resilient characteristics. Goal commitment is an important mediator and predictor to enhance resilience characteristics. This study revealed that goal commitment could improve the protective effect of team resilience when faced these stressors. Being committed to collective goals support sport performers to decide spending effort to reach these goals. In team sports team goals sometimes perceive as individual goals like winning the cup in the league. We can conclude that athletes' level of commitment to team and individual goals within the group become important to build the team and individual resilience. More extended studies examining the contribution of goals and commitment in goal setting process to develop resilient sports team and athletes.

\section{Conflict of Interest}

We assert that there is not any conflict of interest among authors and other parties regarding the present research.

\section{Author Contributions}

Research Idea: EŞ; Research Design: EŞ, MU; Analysis of Data: EŞ, MU; Writing: MU; Critical Review: EŞ

\section{Corresponding Address:}

Doç. Dr. Ender ŞENEL

Muğla Sıtkı Koçman Üniversitesi Spor Bilimleri Fakültesi

Kötekli mah. Sıtkı Koçman Cad. Muğla Sıtkı Koçman Üniversitesi Spor Bilimleri Fakültesi,

Menteş/Muğla 48000

ORCID: https://orcid.org/0000-0001-6276-6704

E-posta: endersenel@mu.edu.tr 


\section{References}

1. Barnett, M. L. (1977). Effects of two methods of goal setting on learning a gross motor task. Research Quarterly. American Alliance for Health, Physical Education and Recreation, 48(1), 19-23.

2. Barnett, M. L., \& Stanicek, J. A. (1979). Effects of goal setting on achievement in archery. Research Quarterly. American Alliance for Health, Physical Education, Recreation and Dance, 50(3), 328-332.

3. Byrne, B. M. (2001). Structural equation modeling with Amos: basic concepts, applications, and programming. Mahwah, NJ: Lawrence Erlbaum Associates.

4. Campion, M. A., \& Lord, R. G. (1982). A control systems conceptualization of the goal-setting and changing process. Organizational Behavior and Human Performance, 30(2), 265-287.

5. Cohen, J. (1988). Statistical power analysis for the behavioral sciences. New York, NY: Routledge Academic.

6. Day, C., \& Gu, Q. (2009). Veteran teachers: commitment, resilience and quality retention. Teachers and Teaching: Theory and Practice, 15(4), 441-457.

7. Decroos, S., Lines, R. L., Morgan, P. B., Fletcher, D., Sarkar, M., Fransen, K., ... \& Vande Broek, G. (2017). Development and validation of the characteristics of resilience in sports teams inventory. Sport, Exercise, and Performance Psychology, 6(2), 158178. https://doi.org/10.1037/spy0000089

8. Erez, M., \& Zidon, I. (1984). Effect of goal acceptance on the relationship of goal difficulty to performance. Journal of Applied Psychology, 69(1), 69-78. https://doi.org/10.1037/0021$\underline{9010.69 .1 .69}$

9. Fasey, K. J., Sarkar, M., Wagstaff, C. R., \& Johnston, J. (2021). Defining and characterizing organizational resilience in elite sport. Psychology of Sport and Exercise, 52, 1-12. https://doi.org/10.1016/j.psychsport.2020.101834

10. Fletcher, D., \& Sarkar, M. (2016). Mental fortitude training: an evidence-based approach to developing psychological resilience for sustained success. Journal of Sport Psychology in Action, 7(3), 135-157. https://doi.org/10.1080/21520704.2016.1255496

11. Galli, N., \& Gonzalez, S. P. (2015). Psychological resilience in sport: a review of the literature and implications for research and practice. International Journal of Sport and Exercise Psychology, 13(3), 243-257. https://doi.org/10.1080/1612197X.2014.946947

12. Gorgulu, R., Senel, E., Adilogulları, İ., \& Yildiz, M. (2018). An adaptation study of measurement properties for the characteristics of resilience in sports team inventory. Education Sciences, 8(3), 1-15. https://doi.org/10.3390/educsci8030139

13. Harrington, D. (2009). Confirmatory factor analysis. Oxford: Oxford university press.

14. Hollenbeck, J. R., \& Klein, H. J. (1987). Goal commitment and the goal-setting process: Problems, prospects, and proposals for future research. Journal of Applied Psychology, 72(2), 212-220. https://doi.org/10.1037/0021-9010.72.2.212

15. Hollingsworth, B. (1975). Effects of performance goals and anxiety on learning a gross motor task. Research Quarterly. American Alliance for Health, Physical Education and Recreation, 46(2), 162-168. https://doi.org/10.1080/10671315.1975.10615319 
16. Hu, L. T., \& Bentler, P. M. (1999). Cutoff criteria for fit indexes in covariance structure analysis: Conventional criteria versus new alternatives. Structural Equation Modeling: A Multidisciplinary Journal, 6(1), 1-55. https://doi.org/10.1080/10705519909540118

17. Kegelaers, J., Wylleman, P., Blijlevens, S., Boonstoppel, A., \& Hendriks, M. (2020). A coaches' perspectives on team resilience during major international competition. International Journal of Sport Psychology, 51(3), 221-246.

18. Klein, H. J., Cooper, J. T., Molloy, J. C., \& Swanson, J. A. (2014). The assessment of commitment: Advantages of a unidimensional, target-free approach. Journal of Applied Psychology, 99, 222-238. https://doi.org/10.1037/a0034751

19. Klein, H. J., Molloy, J. C., \& Brinsfield, C. T. (2012). Reconceptualizing workplace commitment to redress a stretched construct: revisiting assumptions and removing confounds. Academy of Management Review, 37(1), 130-151. https://doi.org/10.5465/amr.2010.0018

20. Locke, E. A. (1968). Toward a theory of task motivation and incentives. Organizational Behavior and Human Performance, 3(2), 157-189. https://doi.org/10.1016/0030-5073(68)90004-4

21. Locke, E. A., Frederick, E., Buckner, E., \& Bobko, P. (1984). Effect of previously assigned goals on self-set goals and performance. Journal of Applied Psychology, 69(4), 694-699. https://doi.org/10.1037/0021-9010.69.4.694

22. Locke, E. A., Shaw, K. R., Saari, L. M., \& Latham, G. P. (1981). Goal setting and task performance: 1968-1980. Psychological Bulletin, 90, 125-152.

23. Lynn, M. R. (1986). Determination and quantification of content validity. Nursing Research, 35(6), 382-385. https://doi.org/10.1097/00006199-198611000-00017

24. Mangundjaya, W. L., \& Amir, M. T. (2021). Testing resilience and work ethics as mediators between charismatic leadership and affective commitment to change. The Journal of Asian Finance, Economics and Business, 8(2), 401-410. https://doi.org/10.13106/JAFEB.2021.VOL8.NO2.0401

25. Martin, A. J., \& Marsh, H. W. (2003, November). Academic resilience and the four cs: confidence, control, composure, and commitment, Paper Presented at the Joint AARE/NZARE Conference / Auckland, New Zealand.

26. Meneghel, I., Salanova, M., \& Martínez, I. M. (2016). Feeling good makes us stronger: how team resilience mediates the effect of positive emotions on team performance. Journal of Happiness Studies, 17(1), 239-255. https://doi.org/10.1007/s10902-014-9592-6

27. Morgan, P. B., Fletcher, D., \& Sarkar, M. (2013). Defining and characterizing team resilience in elite sport. Psychology of Sport and Exercise, 14(4), 549-559. https://doi.org/10.1016/j.psychsport.2013.01.004

28. Morgan, P. B., Fletcher, D., \& Sarkar, M. (2017). Recent developments in team resilience research in elite sport. Current Opinion in Psychology, 16, 159-164. https://doi.org/10.1016/j.copsyc.2017.05.013

29. Morgan, P. B. C., Fletcher, D., \& Sarkar, M. (2019). Developing team resilience: a season-long study of psychosocial enablers and strategies in a high-level sports team. Psychology of Sport and Exercise, 45, 101543. https://doi.org/10.1016/j.psychsport.2019.101543 
30. Morgan, P. B., Fletcher, D., \& Sarkar, M. (2015). Understanding team resilience in the world's best athletes: a case study of a rugby union World Cup winning team. Psychology of Sport and Exercise, 16, 91-100. https://doi.org/10.1016/j.psychsport.2014.08.007.

31. Polit, D. F., \& Beck, C. T. (2006). The content validity index: are you sure you know what's being reported? Critique and recommendations. Research in Nursing \& Health, 29(5), 489-497. https://doi.org/10.1002/nur.20147

32. Riedel, J. A., Nebeker, D. M., \& Cooper, B. L. (1988). The influence of monetary incentives on goal choice, goal commitment, and task performance. Organizational Behavior and Human Decision Processes, 42(2), 155-180. https://doi.org/10.1016/0749-5978(88)90010-6

33. Sarkar, M. (2017). Psychological resilience: definitional advancement and research developments in elite sport. International Journal of Stress Prevention and Wellbeing, 1(3), 1-4.

34. Sarkar, M., \& Fletcher, D. (2014). Psychological resilience in sport performers: a review of stressors and protective factors. Journal of Sports Sciences, 32(15), 1419-1434. https://doi.org/10.1080/02640414.2014.901551

35. Sarkar, M., \& Page, A. E. (2020). Developing individual and team resilience in elite sport: Research to Practice. Journal of Sport Psychology in Action, 1-14. https://doi.org/10.1080/21520704.2020.1861144

36. Senel, E., Yildiz, M., \& Klein, H. J. (2019). The Turkish adaptation of the Klein et al's unidimensional target-neutral commitment (KUT) scale. SPORMETRE The Journal of Physical Education and Sport Sciences, 18(1), 176-186. https://doi.org/10.33689/spormetre.606849

37. Theodorakis, Y. (1996). The influence of goals, commitment, self-efficacy and self-satisfaction on motor performance. Journal of Applied Sport Psychology, 8(2), 171-182. https://doi.org/10.1080/10413209608406475

38. Waltz, C. F., \& Bausell, R. B. (1981). Nursing research: design, statistics, and computer analysis. Philadelphia: F. A. Davis Company.

39. Westfall, P. H., \& Henning, K. S. S. (2013). Texts in statistical science: Understanding advanced statistical methods. Boca Raton, FL: Taylor \& Francis. 